\title{
Note on the Occurrence of Arthopyrenia foveolata at Plymouth.
}

By

\author{
Lily Batten, M.Sc.,Ph.D.
}

WHEN shore-collecting for marine algæ at Plymouth in early April, an organism which has now been identified as a calcareous lichen was brought to my notice by Dr. Orton. It occurred in large patches on the rocks both above and below high-water mark in the neighbourhood of the Marine Biological Station, and was also very frequent on the limpets and barnacles in the vicinity. When examined with a lens, the thallus of the lichen was observed to be thickly dotted either with perithecia or with well-marked pits which had apparently been previously occupied with fruits. The lichen was found to be identical with the species collected in Robin Hood Bay, Yorkshire, by E. M. Holmes, in 1901, and described by A. Lorrain Smith as Arthopyrenia foveolata.* Arthopyrenia differs from Verrucaria in the fact that the associated alga is Trentepohlia, and the above species is easily distinguished by the pits which occur on the thallus.

The same species has been recorded by M. C. Knowles $\dagger \ddagger$ from various places round the coast of Ireland, including the western shore of Blacksod Bay. It occurred on limestone rocks at about high neap-tide level, and also on live and dead barnacles where it was almost always associated with colonies of Rivularia atra. At Plymouth, the frequent occurrence of the lichen on limpet shells is a conspicuous feature in the distribution.

Arthopyrenia is a genus of the Pyrenulace $e$, in which the algal cells are a species of Trentepohtia. It has therefore yellowish filamentous gonidia. A. foveolata is distinguished from the closely allied $A$. litoralis by the fact that the perithecia are foveolate, i.e. almost completely immersed and leaving small pits in the sub-stratum. The perithecia are minute black bodies with the perithecial wall sub-entire, black above, brown below. Paraphyses are very scanty or wanting and not mucilaginous. The asci are cylindrical, clavate, $0.070-80 \mathrm{~mm}$. long, $0.017 \mathrm{~mm}$. thick, and contain 8 spores. Spores uni-septate, colourless, oblong-ovate, thinner at the end, $0.015-18 \mathrm{~mm}$. long, $0.006-7 \mathrm{~mm}$. thick.

Spermogones small, globose or ovid with simple sterigmata and rodlike spermatia.

I should like to express my thanks to Miss Lorrain Smith for her help in identifying the species and in locating references.

* A. L. Smith, " British Lichens," Part II, p. 325. London, 1911

† "Fisheries, Irelanc", Sci. Invest., 1914," III (1915), p. 26.

$\ddagger$ Knowles, "Notes on West Galway Lichens," Irish Naturalist, XXI, 1912, p. 31. 